\title{
Mercury Binding by Methanobactin from Methylocystis strain SB2
}

\author{
Bipin S. Baral ${ }^{\mathrm{a}}$, Nathan L. Bandow ${ }^{\mathrm{a}}$, Alexy Vorobev ${ }^{\mathrm{b}}$, Brittani C. Freemeier ${ }^{\mathrm{a}}$, Brandt H. \\ Bergman $^{\mathrm{a}}$, Timothy J. Herdendorf ${ }^{\mathrm{a}}$, Nathalie Fuentes ${ }^{\mathrm{a}}$, Luke Ellias ${ }^{\mathrm{a}}$, Erick Turpin ${ }^{\mathrm{a}}$, Jeremy \\ D. Semrau ${ }^{\mathrm{b}}$ and Alan A. DiSpirito ${ }^{\mathrm{a}^{*}}$ \\ ${ }^{\mathrm{a}}$ Roy J. Carver Department of Biochemistry, Biophysics and Molecular Biology, Iowa State \\ University, Ames, IA, 50011 \\ ${ }^{\mathrm{b}}$ Department of Civil and Environmental Engineering, The University of Michigan, Ann Arbor, \\ Michigan, 48109-2125
}

Running Title: Hg binding by methanobactin

Keywords: methanobactin, chalkophore, methanotroph, mercury binding, mercury mobilization

*To whom correspondence should be addressed. Alan A. DiSpirito;

Email: aland@ iastate.edu; Phone: (514) 294-2944; Fax: (515) 294-0453 


\begin{abstract}
Methanobactin (mb) is a post-translationally modified copper-binding compound, or chalkophore, secreted by many methane-oxidizing bacteria or methanotrophs in response to copper limitation. In addition to copper, methanobactin from Methylosinus trichosporium OB3b (mb-OB3b) has been shown to bind a variety of metals including $\mathrm{Hg}^{2+}$. In this report, $\mathrm{Hg}$ binding by the structurally unique methanobactin from Methylocystis strain SB2 (mb-SB2) was examined and compared to mb-OB3b. Mb-SB2 is shown to bind the common forms of $\mathrm{Hg}$ found in aqueous environments, $\mathrm{Hg}^{2+}, \mathrm{Hg}(\mathrm{CN})_{2}$ and $\mathrm{CH}_{3} \mathrm{Hg}^{+}$. The spectral and thermodynamic properties of binding for each form of mercury differed. UV-visible absorption spectra suggested $\mathrm{Hg}^{2+}$ binds to both the oxazolone and imidazolone rings of mb-SB2, whereas $\mathrm{CH}_{3} \mathrm{Hg}^{+}$appeared to only bind to the oxazolone ring. $\mathrm{Hg}(\mathrm{CN})_{2}$ showed spectral properties between $\mathrm{Hg}^{2+}$ and $\mathrm{CH}_{3} \mathrm{Hg}^{+}$. Isothermal titration calorimetry (ITC) showed both $\mathrm{Hg}(\mathrm{CN})_{2}$ and $\mathrm{CH}_{3} \mathrm{Hg}^{+}$fit into twosite binding models. For $\mathrm{Hg}(\mathrm{CN})_{2}$ the first site was exothermic and the second endothermic. Both binding sites in $\mathrm{CH}_{3} \mathrm{Hg}^{+}$were exothermic, but at equilibrium the reaction never moved back to the baseline, suggesting a slow residual reaction. ITC results for $\mathrm{Hg}^{2+}$ were more complex and suggested a 3- or 4-site model. The spectral, kinetic and thermodynamic changes following $\mathrm{Hg}$ binding by mb-SB2 also differed from the changes associated with mb-OB3b. Like mb-OB3b, copper did not displace $\mathrm{Hg}$ bound to $\mathrm{mb}-\mathrm{SB} 2$. In contrast to $\mathrm{mb}-\mathrm{OB} 3 \mathrm{~b} \mathrm{Hg}^{2+}$ could displace $\mathrm{Cu}$ from $\mathrm{Cu}$-containing mb-SB2 and preferentially bound $\mathrm{Hg}^{2+}$ over $\mathrm{Cu}^{2+}$ at metal to $\mathrm{mb}-\mathrm{SB} 2$ molar ratios above 1.0 .
\end{abstract}




\section{Introduction}

Methanobactin (mb) is a small, <1,200 Da, post-translationally modified, copper binding compound, or chalkophore, produced by many methane-oxidizing bacteria (methanotrophs) and potentially several non-methanotrophic bacteria as well based on bioinformatic analyses [1 - 4]. The molecule has been structurally characterized in 5 different methanotrophs $[3,5-8]$, and this class of metal-binding peptides is characterized by the presence of one oxazolone ring and a second five or six membered ring, which is either an oxazolone, imidazolone or a pyrazinedione ring (Fig. 1) $[3,5,6]$. Both rings are associated with an enethiol group, which together form the metal coordination site. Depending on the metal, the coordination site consists of one of the rings and its associated enethiol or both rings and associated enethiols [Table S1; 9]. The two rings are separated by 2 to 5 amino acids. Methanobactin from M. trichosporium OB3b (mb-OB3b) and from Methylocystis strain SB2 (mb-SB2) have different rings, amino acid composition, and molecular size. Despite these differences, the copper binding properties of the different forms were similar, suggesting the pair of rings and associated enethiols confer the unique metal binding properties associated with this class of metal binding peptides [1, 6, 7, $10-14]$.

In addition to copper, mb from $M$. trichosporium OB3b (mb-OB3b) has also been shown to bind many transition and post-transition metals (Table S1) [9, 19]. In general, the binding constants for most of the tested metals are well below those observed for copper, and copper will displace most other metals bound to mb-OB3b [9]. However, some metals, such as $\mathrm{Au}^{3+}$ and $\mathrm{Hg}^{2+}$ appear to have binding properties similar to $\mathrm{Cu}^{2+}$, and $\mathrm{Cu}^{2+}$ cannot displace these metals [9]. A recent study by Vorobev et al. [19] demonstrated that mb-OB3b reduced $\mathrm{Hg}$ toxicity to $M$. trichosporium $\mathrm{OB} 3 \mathrm{~b}$ as well as to other methanotrophs even in the presence of $\mathrm{Cu}^{2+}$. That study also showed that when exposed to equimolar concentrations of $\mathrm{Hg}^{2+}$ and $\mathrm{Cu}^{2+}, \mathrm{mb}-\mathrm{OB} 3 \mathrm{~b}$ will 
bind approximately $1 \mathrm{Hg}$ for every $10 \mathrm{Cu}$. Here we extend current analyses of mercury binding by chalkophores by examining the mechanism of mercury binding by $\mathrm{mb}$ from Methylocystis species SB2 (Fig. 1) (mb-SB2). With the exception of the core methanobactin features stated above, the structure of methanobactin from Methylocystis strain SB2 differs from mb-OB3b (Fig. 1). In mb-SB2 the redox active and metal binding amino acids found in mb-OB3b are replaced with Ala or are missing. The disulfide bond providing structural stability in mb-OB3b is also missing in mb-SB2. Thus, a comparison of the properties between these two forms of methanobactins provides a means to determine the role of the protein backbone in the mercury binding properties of the methanobactin.

\section{Materials and methods}

\subsection{Growth and isolation of $m b-S B 2$}

Methylocystis strain SB2 was cultured for mb-SB2 production in NMS medium [20] in sequential batch reactors. To maintain high $(\sim 50 \mu \mathrm{M})$ concentrations of mb-SB2 in the spent medium, the copper concentrations in the reactor were varied, with two turnovers of NMS medium containing $0.2 \mu \mathrm{M} \mathrm{Cu}$ followed by one turnover of NMS media containing $1.0 \mu \mathrm{M}$ $\mathrm{CuSO}_{4}$. This sequence was generally repeated 2 to 4 times. Varying copper concentrations in the culture media maintained high culture density and high concentrations of mb-SB2 in the spent medium.

Mb-SB2 was isolated from the spent medium as previously described [16]. Purity of mbSB2 samples was determined as previously described $[3,8,10,11,16]$. Sample purity was $>97 \%$, with breakdown fragments of mb-SB2 comprising most of the trace contaminants. Mb-SB2 samples used in this study contained less than $0.02 \mathrm{Cu}$ per mb-SB2 as determined by atomic 
absorption spectroscopy described below. Following purification the samples were stored in the dark.

\subsection{Acid hydrolysis of $m b-S B 2$}

Acid hydrolysis of the oxazolone ring in mb-SB2 was carried out in reaction mixtures containing $50 \mu \mathrm{M}$ mb-SB2 in $85 \mu \mathrm{M}$ acetic acid. The reaction mixtures were incubated at $25^{\circ} \mathrm{C}$ for 7-9 $\mathrm{h}$ and monitored by UV-visible spectroscopy to determine the time required for the complete hydrolysis of the oxazolone ring. In contrast to the procedure reported by Krentz et al. [3], the final $\mathrm{pH}$ of the solution was 6.8 and therefore did not require neutralization. The hydrolyzed solutions were kept on ice and used within $12 \mathrm{~h}$ of preparation.

\subsection{Spectroscopy}

UV-visible absorption, fluorescence, and circular dichroism spectroscopy were performed as previously described $[10,16]$. Briefly, either $50 \mu \mathrm{M}$ (for $\mathrm{UV}$-visible absorption and fluorescence) or $500 \mu \mathrm{M}$ (for $\mathrm{UV}$-visible CD) $\mathrm{mb}$-SB2 solutions were prepared in $>18 \mathrm{M} \Omega \cdot \mathrm{cm}$ $\mathrm{H}_{2} \mathrm{O}$ and titrated with $10 \mathrm{mM}$ metal stock solutions of metals also prepared in $>18 \mathrm{M} \Omega \cdot \mathrm{cm}^{\mathrm{H}} \mathrm{H}_{2} \mathrm{O}$. Titrations involved sequential 0.05 or 0.1 molar additions of metal to mb-SB2 pre-loaded into a cuvette and rapidly mixed by hand for $10-20 \mathrm{~s}$. Spectra were taken immediately after mixing.

\subsection{Metal determination}

Copper and mercury were determined on an Agilent 55AA atomic absorption spectrometer (Agilent Technologies Inc., Santa Clara, CA) coupled with a vapor diffusion VGA 77 system and run in either the flame or cold vapor mode for copper or mercury, respectively. 
All measurements were taken in triplicate. Mercury volatilization was determined as described by Takeuchi et al. [21] and modified as previously described by Vorobev, et al. [19].

\section{5. $\mathrm{mb}$-SB2 mediated solubility of $\mathrm{Hg}^{0}$}

The solubility of $\mathrm{Hg}^{0} / \mathrm{Hg}^{2+}$ in the aqueous phase was determined by incubating $\mathrm{Hg}^{0}$ in > $18 \mathrm{M} \Omega \cdot \mathrm{cm} \mathrm{H}_{2} \mathrm{O}$ at room temperature $\left(25 \pm 2^{\circ} \mathrm{C}\right)$. Reaction solutions contained $25 \mu \mathrm{Hg}^{0}$ in 25 $\mathrm{ml}$ of $>18 \mathrm{M} \Omega \cdot \mathrm{cm} \mathrm{H}_{2} \mathrm{O}$ with or without the addition of either $50 \mu \mathrm{M}$ mb-SB2 or $50 \mu \mathrm{M}$ bovine serum albumin (BSA). Reaction mixtures were incubated at room temperature with continuous stirring. Periodically, the stirring was stopped for $30 \mathrm{sec}$ and $1 \mathrm{ml}$ was removed from the top and diluted with $14 \mathrm{ml}$ of $5 \% \mathrm{HCl}, 5 \% \mathrm{HNO}_{3}$ and $90 \% \mathrm{H}_{2} \mathrm{O}(\mathrm{v} / \mathrm{v}) . \mathrm{Hg}$ in the aqueous phase was determined by metal analysis as described above. Similar experiments were performed under anaerobic conditions in an atmosphere of $96 \%$ argon and $4 \%$ hydrogen inside an anaerobic chamber (Coy Laboratories, Michigan, United States). The presence of $\mathrm{O}_{2}$ inside the chamber was monitored via a Coy oxygen/hydrogen meter and by anaerobic indicator strips (Oxoid Ltd, Hants, UK). All solutions were checked for oxygen contamination before and after each experiment using Oxoid anaerobic indicator strips. Mercury concentrations in the aqueous phase were determined by atomic absorption spectroscopy in vapor diffusion mode as described above. Reaction mixtures containing mb-SB2 were also examined by UV-visible absorption spectroscopy. For spectral analysis of samples incubated under anaerobic conditions, the reaction mixtures were loaded into septa-sealable cuvettes, sealed in the Coy chamber and the spectra taken outside the chamber.

\subsection{Kinetics of mercury and copper binding to $m b-S B 2$}


The rates for mercury and copper binding to $\mathrm{mb}-\mathrm{SB} 2$ were determined by measuring absorption changes at $338 \mathrm{~nm}$ and $387 \mathrm{~nm}$, using a four-syringe Biologic SFM/4000/S stopped flow reactor coupled to a MOS-500 spectrophotometer (Bio-Logic Science Instrument SA, Claix, France). Metal stock solutions of $\mathrm{CuCl}_{2}, \mathrm{HgCl}_{2}$, or $\mathrm{Hg}(\mathrm{CN})_{2}$ were prepared in > $18 \mathrm{M} \Omega \cdot \mathrm{cm} \mathrm{H}_{2} \mathrm{O}$. The stock solutions for mb-SB2 were prepared by dissolving freeze-dried mb$\mathrm{SB} 2$ in $>18 \mathrm{M} \Omega \cdot \mathrm{cm} \mathrm{H}_{2} \mathrm{O}$. The stock solutions of $\mathrm{CuCl}_{2}, \mathrm{HgCl}_{2}$ and mb-SB2 were chilled on ice, then filtered through a $0.22 \mu \mathrm{m}$ filter before loading into sample syringes. The final concentration of the stock mb-SB2 after filtration was determined by UV-visible absorption spectroscopy as previously described [15]. The path length for the cuvette used in the Biologic $\mathrm{SFM} / 4000 / \mathrm{S}$ stopped flow reactor was $1.5 \mathrm{~mm}$. The dead time of the system was $1.4 \mathrm{~ms}$. The system was cooled and maintained at $4^{\circ} \mathrm{C}$. The reaction mixture contained $400 \mu \mathrm{M}$ of mb-SB2 and either $40,100,200,240,280,320,360,400,600,700$, or $800 \mu \mathrm{M}$ of $\mathrm{CuCl}_{2}, \mathrm{HgCl}_{2}$, or $\mathrm{Hg}(\mathrm{CN})_{2}$. Rates obtained for each concentration were an average of a minimum of five traces. Traces following metal addition were divided by traces with no metal additions before the traces were fit. The rates were determined by fitting the traces to the exponential function in Biokine operational software (Bio-Logic Science Instrument SA). Binding rates were calculated in mol metal bound per sec per mol mb-SB2 and reported as $\mathrm{s}^{-1}$.

\subsection{Copper and mercury mixed-metal binding experiments}

Binding of mercury and copper in mixed metal conditions by mb-SB2 was determined in solutions containing $\mathrm{CuCl}_{2}, \mathrm{HgCl}_{2}, \mathrm{Hg}(\mathrm{CN})_{2}$ or $\mathrm{CH}_{3} \mathrm{HgCl}$ and mb-SB2 in molar ratios of copper to mercury to methanobactin of $0.25: 0.25: 1,0.5: 0.5: 1,1: 1: 1,1.5: 1.5: 1$, and $2: 2: 1$. The solutions were incubated with stirring $(200 \mathrm{rpm})$ at room temperature for $5 \mathrm{~min}$. Following this incubation 
period, the samples were loaded on to pre-equilibrated Sep-Pak cartridges (Millipore Corporation, Billerica, MA USA) as previously described to separate methanobactin from unbound metal [15]. Sep-Pak cartridges contain hydrophobic reverse-phase C-18 resin. Sep-Pak cartridges were washed with $6 \mathrm{ml}$ of $>18 \mathrm{M} \Omega \cdot \mathrm{cm} \mathrm{H}_{2} \mathrm{O}$ three times, then eluted with $6 \mathrm{ml}$ of 60 $\%$ acetonitrile : $40 \% \mathrm{H}_{2} \mathrm{O}(\mathrm{v} / \mathrm{v})$. Copper and mercury were determined as described above in the reaction mixture, in the wash solution as well as in the sample eluent. Similarly, copper and mercury were measured in control solutions containing: i) mercury and copper only; ii) mercury and mb-SB2 only, and; iii) copper and mb-SB2 only.

\subsection{Displacement of mb-SB2-bound metals}

$\mathrm{AgCl}, \mathrm{FeCl}_{3}, \mathrm{CdCl}_{2}, \mathrm{CoCl}_{2}, \mathrm{NiCl}_{2}, \mathrm{ZnSO}_{4}, \mathrm{PbNO}_{2}$, or $\mathrm{CuCl}_{2}$ was added to mb-SB2 in a molar ratio of 1.1 metal per mb-SB2 and the UV-visible absorption spectrum between 200 and $500 \mathrm{~nm}$ determined. A second metal, either $\mathrm{HgCl}_{2}, \mathrm{Hg}(\mathrm{CN})_{2}$ or $\mathrm{CH}_{3} \mathrm{HgCl}$ was added at an equimolar concentration and the UV-visible absorption spectra measured again. The UV-visible absorption spectra for each metal bound to mb-SB2 is unique (results not shown) and was used to determine displacement. The potential displacement of $\mathrm{Cu}(\mathrm{II})$ by $\mathrm{HgCl}_{2}, \mathrm{Hg}(\mathrm{CN})_{2}$ or $\mathrm{CH}_{3} \mathrm{HgCl}$ was also assayed by metal analysis as described above for mixed-metal binding experiments.

\subsection{Isothermal Titration Calorimetry (ITC)}

ITC measurements were performed at $25^{\circ} \mathrm{C}$ using a GE Microcal ITC200 microcalorimeter (GE Health Sciences, Piscataway, NJ, USA) to determine the affinity of mb$\mathrm{SB} 2$ for different forms of mercury. Titrant solutions were $0.35,1.0$ or $4 \mathrm{mM} \mathrm{CH}_{3} \mathrm{HgCl}, \mathrm{HgCl}_{2}$ 
and $\mathrm{Hg}(\mathrm{CN})_{2}$ were prepared in $>18 \mathrm{M} \Omega \cdot \mathrm{cm} \mathrm{H}_{2} \mathrm{O}$. A100 $\mathrm{mM} \mathrm{CH}_{3} \mathrm{HgCl}$ stock solution was prepared first in $\mathrm{CH}_{3} \mathrm{OH}$ and then diluted to $4 \mathrm{mM}$ with $>18 \mathrm{M} \Omega \cdot \mathrm{cm} \mathrm{H}_{2} \mathrm{O}$ to achieve a final methanol concentration of $4 \%(\mathrm{v} / \mathrm{v})$. Mercury compounds were then injected at volumes ranging from $1-2 \mu 1$ into a cell containing $100 \mu \mathrm{M}$ mb-SB2 stirred at $1000 \mathrm{rpm}$. Injections were added at $180 \mathrm{~s}$ intervals, with the length of each injection pre-determined by instrument software based on the volume of injection. The instrument was cleaned between experiments using $>18 \mathrm{M} \Omega \cdot \mathrm{cm}$ $\mathrm{H}_{2} \mathrm{O}$, and the sample cell also washed according to manufacturer recommendations when sample build-up was observed. Following each titration, the sample cell was also washed with $1-3$ cell volumes of $100 \mu \mathrm{M}$ mb-SB2 to remove any residual metal. The data were analyzed using nonlinear least-squares curve fitting in Origin 7.0 software (GE Health Sciences). Due to fitting limitations of the software, some of the data were fit by hand. Other more unusual titration curves had sections that could not be fit and were listed as unable to fit (UTF). Origin 7.0 software requires the titration curve to return to zero in order to be fitted and in the case of $\mathrm{CH}_{3} \mathrm{HgCl}$ binding to mb-SB2, the entire data curve was shifted along the $\mathrm{y}$-axis by 2000 calories per mole to allow the curve to be fit by the software. Following this shift, the changes in enthalpy $(\Delta \mathrm{H})$ values were corrected by the magnitude of the shift before calculating the change in Gibbs free energy $(\Delta \mathrm{G})$. The stoichiometry for the binding of each form of mercury is indicated in Table 1 as calculated by the binding algorithm used by the Origin software. 


\section{Results}

\subsection{UV-visible absorption spectroscopy}

The addition of $\mathrm{HgCl}_{2}, \mathrm{Hg}(\mathrm{CN})_{2}$, or $\mathrm{CH}_{3} \mathrm{HgCl}$ to mb-SB2 showed absorption changes in the 240 to $300 \mathrm{~nm}$ range characteristic of metal-ligand charge transfer transitions in compounds containing thiol groups (Fig. 2) [ $22-26]$. The shape and absorption maxima in this spectral range have also been shown to differ for different metals bound to the same protein [22, 23], which was also observed in the spectra in this region for the three different forms of mercury (Figs. 2A, 2C and 2E). Based on the UV-visible absorption spectra changes following $\mathrm{HgCl}_{2}$ additions between 0.1 and $0.7 \mathrm{Hg}^{2+}$ per mb-SB2 (Figs. 2A and 2B), $\mathrm{Hg}^{2+}$ appeared to bind to both the oxazolone $(338 \mathrm{~nm})$ and imidazolone $(387 \mathrm{~nm})$ rings of mb-SB2 as evidenced by a decreased absorbance at 338 and $387 \mathrm{~nm}$ associated with the oxazolone and imidazolone rings, respectively. This was accompanied by a red shift of the $387 \mathrm{~nm}$ maxima to $402 \mathrm{~nm}$ with an additional increased absorbance at higher $\mathrm{Hg}^{2+}$ to mb-SB2 molar ratios. $\mathrm{CH}_{3} \mathrm{Hg}^{+}$, however, appeared to only bind to the oxazolone ring as little or no absorbance change at $387 \mathrm{~nm}$ was observed (Figs. 2E and 2F) and required higher ratios of $\mathrm{CH}_{3} \mathrm{Hg}^{+}$per mb-SB2 to saturate the sample ( 2.0 $\mathrm{CH}_{3} \mathrm{Hg}^{+}$per mb-SB2). The UV-visible absorption spectral change following $\mathrm{Hg}(\mathrm{CN})_{2}$ additions had properties in between $\mathrm{HgCl}_{2}$ and $\mathrm{CH}_{3} \mathrm{HgCl}$ and was saturated at 0.5 $\mathrm{Hg}(\mathrm{CN})_{2}$ per mb-SB2 (Figs. $2 \mathrm{C}$ and 2D). It should be noted here that $\mathrm{Hg}(\mathrm{CN})_{2}$ is soluble in $\mathrm{H}_{2} \mathrm{O}$, but the dissociation constant is low and can form complexes such as $\mathrm{Hg}(\mathrm{CN})_{4}{ }^{2-}[27,28]$. The UV-visible absorption spectra as well as the kinetic, metal displacement, fluorescence spectra and thermodynamic data, described below, all suggest mb-SB2 binds $\mathrm{Hg}(\mathrm{CN})_{2}$ or one of the $\mathrm{Hg}$ $\mathrm{CN}$ complexes and not the dissociated $\mathrm{Hg}^{2+}$. 
Previous studies on mb from Methylosinus trichosporium OB3b (mb-OB3b) demonstrated that $\mathrm{CH}_{3} \mathrm{Hg}^{+}$bound to both oxazolone $\mathrm{A}$ and oxazolone $\mathrm{B}$ [19]. In mb-OB3b, the two oxazolone rings are separated by five amino acids, while in mb-SB2 the two rings are separated by only two amino acids suggesting the imidazolone ring does not coordinate $\mathrm{CH}_{3} \mathrm{Hg}^{+}$ due to steric inhibition of the bulky methyl group. To test this hypothesis, the oxazolone group of mb-SB2 was selectively hydrolyzed, which may eliminate this apparent steric inhibition (Figs. S1A and S1B). Based on the UV-visible absorption spectra of the acid-hydrolyzed sample, the imidazolone group of acid-hydrolyzed samples of mb-SB2 failed to bind $\mathrm{CH}_{3} \mathrm{Hg}^{+}$suggesting the imidazolone group does not bind this organic form of Hg (Figs. S1A and S1B). Fluorescence spectra (Figs. S2C and S2D), however, demonstrated acid-hydrolyzed sample does bind approximately one $\mathrm{CH}_{3} \mathrm{Hg}^{+}$per mb-SB2. The decreased absorption in the $240-300 \mathrm{~nm}$ range of suggests $\mathrm{CH}_{3} \mathrm{Hg}^{+}$binds to the enethiol groups in the absence of the oxazolone ring (Fig. S1A). Steric inhibition by methyl group may still be responsible for the inability of the imidazolone ring to coordinate $\mathrm{CH}_{3} \mathrm{Hg}^{+}$, but this inhibition could not be verified by elimination of the oxazolone ring.

Under aerobic conditions, mb-SB2 appeared to increase the solubility of metallic $\mathrm{Hg}^{0}$ as determined by its increased concentration in the aqueous phase and by the changes in the UVvisible absorption spectra of mb-SB2 in the reactions mixtures containing $\mathrm{Hg}^{0}$ (Figs. S3A and S3C). However, the UV-visible absorption spectral changes following incubation in the presence of $\mathrm{Hg}^{0}$ were identical to $\mathrm{Hg}^{2+}$ suggesting $\mathrm{Hg}^{0}$ was first oxidized to $\mathrm{Hg}^{2+}$ and then bound by mbSB2 (Fig. 2 and S3A). A similar result could be obtained by the addition of a non-reactive protein, bovine serum albumin again suggesting the adventitious binding of $\mathrm{Hg}^{2+}$ to bovine serum albumin following the chemical oxidation of $\mathrm{Hg}^{0}$ (Fig. S3C). To verify this observation, 
these experiments were repeated under anoxic conditions. Under such conditions, $\mathrm{no}^{2+} \mathrm{Hg}^{2+}$ was detected in the aqueous phase, nor were spectral changes observed in mb-SB2 confirming mbSB2 bound $\mathrm{Hg}^{2+}$ following the chemical oxidation of $\mathrm{Hg}^{0}$ (results not shown).

Volatile $\mathrm{Hg}^{0}$ was never observed, suggesting no reduction of $\mathrm{Hg}^{2+}$ to $\mathrm{Hg}^{0}$. Reduction of $\mathrm{Hg}^{2+}$ was expected, since both mb-OB3b and mb-SB2 have been shown to reduce $\mathrm{Cu}^{2+}$ to $\mathrm{Cu}^{+}$ and mb-OB3b to reduce $\mathrm{Au}^{3+}$ to $\mathrm{Au}^{0}[9-11]$. If reduction does occur, $\mathrm{Hg}$ remained associated with mb-SB2.

\subsection{Fluorescence spectroscopy}

With one exception, the fluorescence spectra following excitation at $341 \mathrm{~nm}$ and mercury addition to mb-SB2 differed from the spectra following copper addition [11]. As observed following copper addition, all three forms of mercury resulted in an increased emission at 427 $441 \mathrm{~nm}$ (Figs. 3A, 3C and 3E). In the case of $\mathrm{Cu}^{2+}$, the increase in emission stopped at a copper to mb-SB2 molar ratios of $0.4 \mathrm{Cu}$ per mb-SB2 [11]. With mercury, the increase in emission continued at $\mathrm{Hg}$ to mb-SB2 molar ratios between 2.0 and 6.0 depending on excitation wavelength and form of mercury added. In all cases, the increased emissions continued well beyond the saturation points observed for UV-visible absorption spectra, UV-visible CD spectra or ITC titrations (described below).

The increased emissions cannot be explained solely by internal quenching between the imidazolone and oxazolone rings, since a similar trend was observed following hydrolysis of the oxazolone ring (Fig. S2). In fact, as observed following $\mathrm{Cu}^{2+}$ addition [11], the intensity of the emission spectra following $\mathrm{Hg}$ additions increased approximately two fold following acidhydrolysis of the oxazolone ring. As previously observed [11], the emission spectra at $417 \mathrm{~nm}$ 
following excitation at $341 \mathrm{~nm}$ and following hydrolysis of the ring suggest the fluorescence properties of mb-SB2 is associated with the imidazolone ring (Fig. S2). The increased emission may be due to the binding of $\mathrm{Hg}$ to other functional groups in the molecule or to $\mathrm{Hg}^{2+}$ reduction to $\mathrm{Hg}^{+}$or $\mathrm{Hg}^{0}$ followed by aggregate formation [29].

Following excitation at $394 \mathrm{~nm}$ and the addition of $\mathrm{HgCl}_{2}, \mathrm{Hg}(\mathrm{CN})_{2}$ or $\mathrm{CH}_{3} \mathrm{HgCl}$, the emission at $610 \mathrm{~nm}$ decreased and the emission at $441 \mathrm{~nm}$ increased (Fig. 3B, 3D, and 3F). The emission intensity at $441 \mathrm{~nm}$ following $\mathrm{HgCl}_{2}$ addition was particularly unusual. The emission at $441 \mathrm{~nm}$ initially increased in a broad peak between 0 and $1.0 \mathrm{Hg}$ per mb-SB2. This emission was followed by a decrease between $1.0-2.0 \mathrm{Hg}$ per mb-SB2, and then by a splitting of the peak at higher $\mathrm{Hg}$ to mb-SB2 molar ratios (Fig. 3B). As observed following excitation at $341 \mathrm{~nm}$, the intensity of the emission spectra following $\mathrm{Hg}$ additions increased approximately two fold following acid hydrolysis of the oxazolone ring (Figs. S2A and S2C).

\subsection{UV-visible circular dichroism spectroscopy}

As observed in mb-OB3b and other small molecules the UV-CD of mb-SB2 in the absence of any added metal was of an unordered polypeptide with strong negative shoulders at $202 \mathrm{~nm}$ and $223 \mathrm{~nm}$ and a positive band at $300 \mathrm{~nm}$ (Fig. 4A). The addition of $\mathrm{Cu}^{2+}$ resulted in a shift of the 202 to $215 \mathrm{~nm}$ and increased positive intensity at $264 \mathrm{~nm}$ between 0.1 and $0.5 \mathrm{Cu}^{2+}$ per mb-SB2 followed by a decreased at higher $\mathrm{Cu}^{2+}$ to mb-SB2 molar ratios (Fig. $4 \mathrm{~B}$ and E). The UV-CD spectra following addition of $\mathrm{Hg}^{2+}$ differed from the spectra following $\mathrm{Cu}^{2+}$ addition. Specifically, there was little to no change in the $202 \mathrm{~nm}$ range but a major increase in absorption at $242 \mathrm{~nm}$ at $\mathrm{Hg}^{2+}$ to mb-SB2 between 0.1 and $0.75 \mathrm{Hg}^{2+}$ per mb-SB2. At higher $\mathrm{Hg}^{2+}$ to mbSB2 molar ratios this absorption decreased (Figs. 4B and 4E verses Figs. 4C and 4F). The CD 
bands at 264 or at $242 \mathrm{~nm}$ following $\mathrm{Cu}^{2+}$ addition or $\mathrm{Hg}^{2+}$ addition, respectively, can be assigned to the metal-enethiol charge transfer transitions [23-25].

In contrast to the UV-CD spectra, the visible-CD spectra were complex following metal addition. The major properties of the $\mathrm{CD}$ spectra from mb-SB2 did not coincide with the absorption maxima suggesting potential charge transfer evens between the oxazolone and imidazolone rings (Fig. 4A) [30, 31]. Surprisingly, the intensity of the visible CD bands from mb-SB2 were approximately 100-fold high than that observed with mb-OB3b, which is probably a reflection of either the shorter distance between the oxazolone and imidazolone rings and/or to the absence of the disulfide bond in mb-SB2.

To assign the CD signals to each ring, the oxazolone ring was selectively hydrolyzed. Unfortunately, hydrolysis of the oxazolone ring in mb-SB2 resulted in the loss of all visible-CD properties in the absence of added metals (Fig. 4A and S4). The visible absorbance maximum associated with the imidazolone ring $(387 \mathrm{~nm})$ was not affected by this treatment suggesting the $\mathrm{CD}$ bands in this region results from the dipolar interaction between the rings. New $\mathrm{CD}$ bands in the visible-CD occurred following the binding of $\mathrm{Cu}^{2+}$ (Fig. 4B) or $\mathrm{Hg}^{2+}$ (Fig. 4C) and allows assignment of the $\mathrm{CD}$ maxima at 300 and $380 \mathrm{~nm}$ to the imidazolone ring and at $343 \mathrm{~nm}$ to the oxazolone ring.

The addition of $\mathrm{Cu}^{2+}$ (Fig. 4B) or $\mathrm{Hg}^{2+}$ (Fig. 4C) resulted in an increased molar ellipticity as well as the development of coupled oscillators or an exciton couple, suggesting dimer formation [32 - 34]. Consistent with dimer formation, the maximal changes in the CD spectra were observed at a molar ratio of 0.5 to 0.7 metal per mb-SB2. At higher ratios, such changes were reduced, suggesting dimer dissociation (Fig. 4E and 4F). Comparison of the $\mathrm{CD}$ spectra following addition of $\mathrm{CuCl}_{2}$ (Fig. 4B), $\mathrm{HgCl}_{2}$ (Fig. 4C) and $\mathrm{CH}_{3} \mathrm{HgCl}$ (Fig. 4D) suggested the 
following: (1) the rotation following $\mathrm{Cu}^{2+}$ and $\mathrm{Hg}^{2+}$ binding are in opposite directions, and, (2) the conformational changes following $\mathrm{CH}_{3} \mathrm{HgCl}$ additions were comparatively minor (Fig. 4D). Previous studies on mb-OB3b demonstrated the metals that are coordinated by both rings utilize a two-step mechanism. The first step involves metal binding to one ring followed by a conformational change and then coordination to the second ring [9]. On the other hand, metals that bind to only one of the rings show comparatively minor conformational changes as determined by the $\mathrm{CD}$ spectra following metal additions. The $\mathrm{CD}$ spectra following $\mathrm{CH}_{3} \mathrm{Hg}^{+}$ binding by mb-SB2 showed a similar trend, again suggesting the imidazolone group is not involved in $\mathrm{CH}_{3} \mathrm{Hg}^{+}$coordination to $\mathrm{mb}-\mathrm{SB} 2$.

\subsection{Isothermal titration calorimetry (ITC).}

Of the forms of mercury examined, only $\mathrm{Hg}(\mathrm{CN})_{2}$ fit directly as two-site model (Table 1; Fig. 5D). The $\mathrm{Hg}(\mathrm{CN})_{2}$ titration also differed from the other mercury titrations in that the second binding site was endothermic. Both results were unexpected, since mb-SB2 does not bind $\mathrm{CN}^{-}$ as measured by ITC, nor were any changes observed in the UV-visible absorption or fluorescence spectra following $\mathrm{CN}^{-}$addition, suggesting little to no coordination of $\mathrm{CN}^{-}$to $\mathrm{mb}$ $\mathrm{SB} 2$, the results thus suggest mb-SB2 binds $\mathrm{Hg}(\mathrm{CN})_{2}$ or one of the $\mathrm{Hg}-\mathrm{CN}$ complexes and not the dissociated $\mathrm{Hg}^{2+}$.

$\mathrm{CH}_{3} \mathrm{HgCl}$ also fit a two-site model (Fig. 5C), however, the $\mathrm{CH}_{3} \mathrm{HgCl}$ titrations never moved back to zero as it approached equilibrium, i.e. at equilibrium each titration remained exothermic. The heat of dilution due to the mixing of the organic and aqueous phases was accounted for before attempting to fit the data, as was the addition of $\mathrm{CH}_{3} \mathrm{HgCl}$ in $4 \%$ methanol solution to $\mathrm{H}_{2} \mathrm{O}$. However, a consistent thermodynamic change remained after reaching a molar 
ratio of 2:1 $\mathrm{CH}_{3} \mathrm{HgCl}$ to $\mathrm{mb}-\mathrm{SB} 2$ (Fig $5 \mathrm{C}$ ). The residual heat may be a consequence of the high affinity thiol groups for $\mathrm{CH}_{3} \mathrm{Hg}^{+}$[37]. $\mathrm{Mb}-\mathrm{SB} 2$ has two enethiol groups and $2 \mathrm{CH}_{3} \mathrm{Hg}^{+}$per mbSB2 was required before the residual thermodynamic stabilized, whereas the equilibrium for both $\mathrm{HgCl}_{2}$ and $\mathrm{Hg}(\mathrm{CN})_{2}$ was reached at 0.5 (Fig. 5A, 5B, and 5C). However, association to the thiol groups does not account for the consistent change in heat content as the ratio of $\mathrm{CH}_{3} \mathrm{Hg}^{+}$per mb-SB2 increased above 2.0. The consistent thermodynamic change per injection may result from a $\mathrm{CH}_{3} \mathrm{Hg}^{+}$ligand exchange with the already bound $\mathrm{CH}_{3} \mathrm{Hg}-\mathrm{S}-\mathrm{R}$ [38]. This potential ligand exchange would also account for the decreased thermodynamic change at higher $\mathrm{CH}_{3} \mathrm{Hg}^{+}$. As described in Materials and Methods, the entire data curve was shifted along the y-axis by 2000 calories per mole in order to fit the $\mathrm{CH}_{3} \mathrm{HgCl}$ titration into a two-site model. Following this shift, the enthalpy $(\Delta \mathrm{H})$ values were corrected by the magnitude of the shift before calculating the Gibbs free energy $(\Delta \mathrm{G})$. Data from $\mathrm{HgCl}_{2}$ were more complex and suggested a three or foursite binding model. This complexity made fitting of the data to particular segments of the $\mathrm{HgCl}_{2}$ curve impossible. Segments of the titration curves that could not be fit are listed as unable to fit (UTF) (Table 1).

\subsection{Kinetics of $\mathrm{Cu}^{2+}$ and $\mathrm{Hg}^{2+}$ binding}

The time course for the binding of $\mathrm{Cu}^{2+}, \mathrm{Hg}^{2+}$ and $\mathrm{Hg}(\mathrm{CN})_{2}$ to the oxazolone and imidazolone rings in mb-SB2 were measured as the decrease in absorbance at 341 and $389 \mathrm{~nm}$, respectively, following stopped-flow mixing of mb-SB2 with $\mathrm{Cu}^{2+}, \mathrm{Hg}^{2+}$, or $\mathrm{Hg}(\mathrm{CN})_{2}$. The reaction was monitored at $4^{\circ} \mathrm{C}$, since at $25^{\circ} \mathrm{C}$ less than $10 \%$ of the total absorbance change remained following stopped-flow mixing of the reaction sample (1.4 ms). However, even at $4^{\circ} \mathrm{C}$, initial $\mathrm{Cu}^{2+}$ binding rates could only be determined to the oxazolone ring. Binding rates to 
the oxazolone ring increased with increasing copper at low $\mathrm{Cu}^{2+}$ to $\mathrm{mb}-\mathrm{SB} 2$ ratios with a maximum value of $496 \pm 10 \mathrm{~s}^{-1}$ at $0.25 \mathrm{Cu}^{2+}$ per mb-SB2 (Fig. S5, Table S2). Between 0.25 to $1.0 \mathrm{Cu}^{2+}$, the rate decreased to $143 \pm 3 \mathrm{~s}^{-1}$ at $1.0 \mathrm{Cu}^{2+}$ per mb-SB2. Above $1.0 \mathrm{Cu}^{2+}$ per mb-SB2 the rate increased to $>2000 \mathrm{~s}^{-1}$. The observation that different trends were observed at different copper to mb ratios is common to both mb-OB3b and mb-SB2 [10, 11]. Previous studies have shown different spectral and thermodynamic properties of mb-OB3b and mb-SB2 at $\mathrm{Cu}^{2=}$ to $\mathrm{mb}$ ratios below 0.25 metal to $\mathrm{mb}$ ratio, at $\mathrm{Cu}^{2+}$ to $\mathrm{mb}$ ratios between $0.25-0.5$, at $\mathrm{Cu}^{2+}$ to $\mathrm{mb}$ ratio between 0.5 to 1.0 and at $\mathrm{Cu}^{2+}$ to $\mathrm{mb}$ ratios above $1.0[3,9-12]$. The results in figure $\mathrm{S} 5$ are consist with a model proposing that mb binds as a tetramer at low metal to mb ratios, as a dimer at metal to $\mathrm{mb}$ ratios between 0.25 and $0.5 \mathrm{mb}$ and as a monomer above 1.0 metal per mb. The decreasing rates between 0.25 and $1.0 \mathrm{Cu}^{2+}$ per mb-SB2 may reflect the transitions from a tetramer to a dimer then to a monomer.

Between 40 and $100 \%$ of the reaction was complete at $4{ }^{\circ} \mathrm{C}$ following stopped-flow mixing of $\mathrm{Hg}^{2+}$ to $\mathrm{mb}-\mathrm{SB} 2(1.4 \mathrm{~ms})$. Only minor $(<12 \%$ of the total absorbance change $)$ secondary binding rates could be measured to the oxazolone and imidazolone rings (Table $\mathrm{S} 3) . \mathrm{Hg}(\mathrm{CN})_{2}$ binding rates by mb-SB2 could not be determined since $100 \%$ of the reaction was complete before mixing of the reaction mixture was complete (data not shown).

\subsection{Metal binding in the presence of both $\mathrm{Cu}^{2+}$ and $\mathrm{Hg}^{2+}$}

To determine if mb-SB2 bound $\mathrm{Hg}^{2+}, \mathrm{Hg}(\mathrm{CN})_{2}$ (or one of its dissociated forms) or $\mathrm{CH}_{3} \mathrm{Hg}^{+}$in the presence of $\mathrm{Cu}^{2+}, \mathrm{mb}-\mathrm{SB} 2$ was incubated in the presence of both metals at different mercury to copper to mb-SB2 molar ratios. Preliminary analysis via UV-visible absporption spectroscopy indicated mb-SB2 does not bind $\mathrm{Hg}(\mathrm{CN})_{2}$ or $\mathrm{CH}_{3} \mathrm{Hg}^{+}$in the presence 
of $\mathrm{Cu}^{2+}$. However, UV-visible absorption as well as copper and mercury analysis of the metals bound to mb-SB2 in the presence of both $\mathrm{Cu}^{2+}$ and $\mathrm{Hg}^{2+}$ demonstrated the binding of both metals (Fig. 6). At substochiometric concentrations of $\mathrm{Cu}^{2+}$ and $\mathrm{Hg}^{2+}$ mb-SB2 showed a slight preference for $\mathrm{Cu}^{2+}$. However, at $\mathrm{Cu}^{2+}$ and $\mathrm{Hg}^{2}$ to mb-SB2 at or above saturation, mb-SB2 preferentially bound $\mathrm{Hg}^{2+}$ over $\mathrm{Cu}^{2+}$ (Fig. 6).

\subsection{Metal displacement.}

Based on the results from the mixed metal experiments, the capacity of mercury compounds to displace metals bound to mb-SB2 was examined. $\mathrm{Hg}^{2+}, \mathrm{Hg}(\mathrm{CN})_{2}$ and $\mathrm{CH}_{3} \mathrm{Hg}^{+}$ was found to displace $\mathrm{Fe}^{3+}, \mathrm{Co}^{2+}, \mathrm{Ni}^{2+}, \mathrm{Zn}^{2+}$, and $\mathrm{Pb}^{2+} . \mathrm{Hg}^{2+}$ was also found to displace $\mathrm{Cd}^{2+}$, $\mathrm{Ag}^{+}$and $\mathrm{Cu}^{2+}$ from mb-SB2 (Table S4). The displacement of $\mathrm{Cu}$ from mb-SB2 was surprising considering the high binding constant for $\mathrm{Cu}^{2+}[11]$. To determine the displacement rate the decrease in absorbance at $324 \mathrm{~nm}$ was measured at $4^{\circ} \mathrm{C}$ (Fig. S6). The displacement showed an initial fast rate, $118 \pm 0.2 \mathrm{~s}^{-1}$, representing $\sim 25 \%$ of the total reaction followed by a slow rate of $1.6 \pm 0.1 \mathrm{~s}^{-1}$

\section{Discussion}

Methanobactin appears to be the extracellular component of a copper acquisition system used by many methanotrophs $[1,2,19]$. Consistent with its role in copper acquisition, the $\mathrm{Cu}$ binding constants for both mb-OB3b and mb-SB2 are $>10^{21} \mathrm{M}^{-1}[10,11]$. In addition to $\mathrm{Cu}, \mathrm{mb}-$ $\mathrm{OB} 3 \mathrm{~b}$ has been shown to bind a variety of metals including $\mathrm{Hg}[18,19]$. Recent studies have also demonstrated that mb-OB3b will reduce the toxicity of $\mathrm{Hg}$ to the host organism as well as to other bacterial species tested even in the presence of $\mathrm{Cu}[19]$. In this report we show that mb from Methylocystis strain SB2 also binds the common forms of $\mathrm{Hg}$ found in the environment. 
Although mb-OB3b and mb-SB2 have some similarities, they also represent the known diversity of methanobactins. For example, mb-OB3b forms a cross-linked cyclic structure and is partially composed of the redox active amimo acids, Met, Tyr and Cys. Further, the two oxazolone rings of mb-OB3b are separated by five amino acids. Mb-SB2 is a much simpler molecule, with only two amino acids separating the oxazolone and imidazolone rings, and the reactive amino acids found in mb-OB3b are either missing or replaced with Ala. Thus, a comparison of mercury binding properties by these structurally different forms of methanobactin provides a means to determine the role of the peptide backbone in the mercury binding. Previous comparisons in $\mathrm{Cu}^{2+}$ between mb-OB3b and mb-SB2 showed similar $\mathrm{Cu}$ binding properties [10, 11]. The results presented here also suggest that the capacity to bind different forms of mercury is a common property of chalkophores. However, in contrast to the copper-binding properties, these two forms of methanobactin show different mercury binding properties. Regardless of the $\mathrm{Hg}: \mathrm{Cu}$ : mb-OB3b molar ratio, the $\mathrm{Hg}$ to $\mathrm{Cu}$ molar ratio bound by mb-OB3b never exceeded $0.1 \mathrm{Hg}$ to 1 $\mathrm{Cu}$ [14]. Mb-SB2 on the other hand showed a $\mathrm{Hg}$ to $\mathrm{Cu}$ molar ratio between 0.5 to 6 depending on the $\mathrm{Hg}: \mathrm{Cu}$ : mb-SB2 ratio. Also in contrast to mb-OB3b, $\mathrm{Hg}^{2+}$ was shown here to displace $\mathrm{Cu}$ from copper containing mb-SB2 and the displacment rate suggested an active process.

One unexplained observation in this study was the increased fluorescence emissions of mb-SB2 following mercury binding. Increased emission was observed following $\mathrm{Cu}^{2+}$ addition to mb-SB2, however, the increase was comparatively small [11]. Increased emissions are often observed following the physical disruption of two closely associated chromophores where exciton transfer occurs. [29-41]. The only chromophores in mb-SB2 are the imidazolone and oxazolone rings. If internal quenching does occur, elimination of the oxazolone ring should increase emission from the imidazolone ring, which is what was observed here. However, 
increased emissions from the imidazolone ring continued following mercury addition even in the absence of the oxazolone ring, suggesting an additional mechanism is involved. This second mechanism could not be determined from the data collected.

The results presented here also demonstrate that the binding of mercury compounds by methanobactin is a function of the heterocyclic rings and associated enethiols. The rest of the molecule appears to only provide the structure to coordinate the metal binding rings and enethiol groups in an appropriate conformation. However, the structural differences between mb-SB2 and mb-OB3b appear to influence the mechanism of coordination and kinetics of binding. For example, mb-SB2 shows a greater capacity to bind $\mathrm{Hg}^{2+}$ in the presence of copper than does mb-OB3b [19]. On the other hand, only the oxazolone ring and the two enethiols in mb-SB2 appear capable of binding $\mathrm{CH}_{3} \mathrm{Hg}^{+}$, whereas both oxazolone rings and enethiols of mb-OB3b are involved in $\mathrm{CH}_{3} \mathrm{Hg}^{+}$coordination [19]. The inability of the imidazolone ring in mb-SB2 to coordinate $\mathrm{CH}_{3} \mathrm{Hg}^{+}$may reflect the overall structural differences between the two methanobactins, but the results presented here suggest the difference is due to the inability of the imidazolone ring to coordinate $\mathrm{CH}_{3} \mathrm{Hg}^{+}$. Three types of rings have been identified in the five structurally characterized methanobactins $[3,5-8]$, oxazolone, imidazolone and pyrazinedione rings, and the results presented here indicate the different rings may confer different properties to the molecule.

\section{Conclusions}

The data presented in this report demonstrate that different forms of methanobactin, mb$\mathrm{OB} 3 \mathrm{~b}$ and $\mathrm{mb}-\mathrm{SB} 2$, bind both inorganic and organic forms of mercury and that the binding properties are dependent on the two rings and associated enethiol groups. However, the results also demonstrate that in contrast to mb-OB3b, mb-SB2 will preferentially bind $\mathrm{Hg}^{2+}$ over $\mathrm{Cu}^{2+}$. 
The data also suggest the structurally more rigid and complex mb-OB3b is a more selective $\mathrm{Cu}^{2+}$ binding molecule. $\mathrm{Mb}-\mathrm{SB} 2$, on the other hand, behaves more like the copper-binding protein metallothionine [25], and will preferentially bind other metals such as $\mathrm{Hg}$ over $\mathrm{Cu}$. The preferential binding of $\mathrm{Hg}$ suggest the enethiol groups in mb-SB2 may serve a more prominent role in metal binding than observed in mb-OB3b.

In addition to the environmental implications in the binding of toxic metals, the capacity to bind toxic metals may also have medical applications. In rat models, mb-OB3b has been shown to be an effective treatment for Wilson disease, a genetic defect in the copper-transporting ATPase7B resulting in copper accumulation and liver failure [43, 44]. Intravenous application of methanobactin results in the prompt release of copper from the liver into the bile [40]. Based on the results presented here, methanobactin, especially mb-SB2, may prove an effective treatment for mercury poisoning.

\section{Abbreviations}

$\begin{array}{ll}\mathrm{Cu}-\mathrm{mb}-\mathrm{OB} 3 \mathrm{~b} & \text { copper containing methanobactin from } \text { M. trichosporium } \mathrm{OB} 3 \mathrm{~b} \\ \mathrm{Cu}-\mathrm{mb}-\mathrm{SB} 2 & \text { copper containing methanobactin from Methylocystis strain } \mathrm{SB} 2 \\ \mathrm{ITC} & \text { isothermal titration calorimetry } \\ \mathrm{mb} & \text { methanobactin } \\ \mathrm{mb}-\mathrm{OB} 3 \mathrm{~b} & \text { methanobactin from } \text { M. trichosporium } \mathrm{OB} 3 \mathrm{~b} \\ \mathrm{mb}-\mathrm{SB} 2 & \text { methanobactin from Methylocystis strain } \mathrm{SB} 2 \\ \mathrm{NMS} & \text { nitrate mineral salts } \\ \mathrm{UTF} & \text { unable to fit }\end{array}$




\section{Acknowledgements}

We thank Dr. V. Frasca at GE Microcal for assistance in modeling the ITC results. This research was supported by the Office of Science (BER), U.S. Department of Energy (JDS and ADS) and the National Science Foundation (CHE10112271) (ADS) . Use of the ITC and stopped-flow systems were made possible through a generous gift from the Roy J. Carver Charitable Trust (Muscatine, Iowa). 


\section{References}

[1] J.D. Semrau, A.A. DiSpirito, S. Yoon, FEMS Microbiol. Rev. 34 (2010) 496 - 531.

[2] J.D. Semrau, S. Jagadevan, A.A. DiSpirito, A. Khalifa, J. Scanlan, B.Bergman, B.C.

Freemeier, B.S. Baral, N.B. Bandow, A. Vorobev, D.H. Haft, S. Vuilleumier, J.C. Murrell, Environ. Microbiol. 15 (2013) 3077-3086.

[3] B.D. Krentz, H.J. Mulheron, J.D. Semrau, A.A. DiSpirito, N.L. Bandow, D.H. Haft, S.Vuilleumier S, J.C. Murrell, M.T. Mc.Ellistrem, S.C. Hartsel, W.H. Gallagher, Biochemistry 49 (2010) 10117-10130.

[4] G.E. Kenny and A.C. Rosenzweig, BMC Biology 11 (2013) 17.

[5] H.J. Kim, D.W. Graham, A.A. DiSpirito, D. Alterman, M.A.N. Galeva, C.K. Larive, D. Asunskis, P. Sherwood, Science 305 (2004) 1612 - 1615.

[6] A. El Ghazouani, A. Baslé, S.J. Firbank, C.W. Knapp, J. Gray, D.W. Graham, C. Dennison, Inorg. Chem. 50 (2011) $1378-1391$.

[7] A. El Ghazouani, A. Baslé, J. Gray, D.W. Graham, S.J. Firbank, C. Dennison, Proc. Natl. Acad. Sci. USA 109 (2012) 8400 - 8404.

[8] L.E. Behling, S.C. Hartsel, D.E. Lewis, A.A. DiSpirito, L.R. Masterson, G. Veglia, W.H. Gallagher, J. Am. Chem. Soc.130 (2008) 12604 - 12605.

[9] D.W. Choi, Y.S. Do, C.J. Zea, M.T. McEllistrem, S.W. Lee, J.D. Semrau, N.K. Pohl, C.J. Kisting, L.L.Scardino, S.C. Hartsel, E.S. Boyd, G.G. Geesey, P.H. Shafe, T.P. Riedel, K.A. Kranski, J.R. Tritsch, W.E. Antholine, A.A. DiSpirito, J. Inorgan. Biochem. 100 (2006) 2150 -2161 .

[10] D.W. Choi, C.J. Zea, Y.S. Do, J.D. Semrau, W.A. Antholine, M.S. Hargrove, Pohl NL, E.S. Boyd ES, G.G. Geesey, S.C. Hartsel, P.H. Shafe, M.T. McEllistrem, C.J. Kisting, D. 
Campbell, V. Rao V, A.M. de la Mora AM, A.A. DiSpirito, Biochemistry. 45 (2006) 1142 1153.

[11] N.L. Bandow, V.S. Gilles, B.C. Freesmeier, J.D. Semrau, B. Krentz, W.H. Gallagher, M.T. McEllistrem, S.C. Hartsel, D.W. Choi, H.S. Hargrove, T.M. Heard, L.M. Chesner, K.M. Braunreiter, B.V. Cao, M.M. Gavitt, J.Z. Hoopes, J.M. Johnson, E.M. Polster, B.D. Schoenick', A.M. Umlauf, A.A. DiSpirito, J. Inorg. Chem. 110 (2012) 72 - 82.

[12] D.W. Choi, J.D. Semrau, W.E. Antholine, S.C. Hartsel, R.C. Anderson, J. Carey, A.M. Dreis, E.M. Kenseth, J.M. Renstrom JM, L.L. Scardino, G.S. Van Gorden, A.A. Volkert, A.D. Wingad, P.J. Yanzer PJ, M.T. McEllistrem, A.M. de la Mora, A.A. DiSpirito, J. Inorg. Biochem. 102 (2008) $1571-1580$.

[13] D.W. Choi, W.A. Antholine, Y.S. Do, J.D. Semrau, C.J. Kisting, R.C. Kunz, D. Cambel, V. Rao, S.C. Hartsel, A.A. DiSpirito, Microbiology 151 (2005) 3417 - 3426.

[14] J.A. Zahn, A.A. DiSpirito, J. Bacteriol. 178 (1996) 1018 - 1029.

[15] C.M. Tellez, K.P. Gaus, D.W. Graham, R.G. Arnold, R.Z. Guzman, Appl. Environ. Microbiol. 64 (1998) $1115-1122$.

[16] N.L. Bandow, W.H. Gallager, L. Behling, D.W. Choi, J.D. Semrau, S.C. Hartsel, V.S. Gilles VS, A.A. DiSpirito, Meth. Enzymol. 495 (2011) 260 - 269.

[17] S. Yoon, S.M. Kraemer, A.A. DiSpirito, J.D. Semrau, Environ. Microbiol. 2 (2010) 295 303.

[18] S. Yoon, A.A. DiSpirito, S.M. Kraemer, J.D. Semrau, Meth. Enzymol. 495 (2011) 248 -259. [19] A. Vorobev, S. Jagadevan, B.S. Baral, A.A. DiSpirito, B.C. Freemeier, B.H. Bergman, N.L. Bandow, J.D. Semrau, Appl. Environ. Microbiol. 79 (2013) 5918 - 5926.

[20] R. Whittenbury, K.C. Phillips, J.F. Wilkinson, J Gen Microbiol 61 (1070) 205-218. 
[21] F. Takeuchi, A. Negishi, T. Maeda, K. Kamimura, T. Sugio, J. Biosci. Bioeng. 95 (2003) $239-244$.

[22] M. Vasàk, J.H. Kägi, H.A.O. Hill, Biochemistry 20 (1981) 2852-2856.

[23] K.B. Nielson, D.R. Wingel, J. Biol. Chem. 258 (1983) 13063 - 13069.

[24] J.H. Kägi, B.L. Vallee, J.M Carlson, J. Biol. Chem. 236 (1961) 2435 - 2442.

[25] K.B. Nielson, C.L. Atkin, D.R. Winge, J. Biol. Chem. 260 (1985) $5342-5350$.

[26] G.K. Carson, P.A.W. Dean, M.J. Stillman, Inorgan. Chim. Acta. 56 (1981) 59 - 71.

[27] W.M. Lattamer, J.H. Hildebrand, Reference Book of Inorganic Chemistry (1940) The Macmillian Co., NY.

[28] M.T. Beck, Pure Appl. Chem. 59 (1987) 1703 - 1720.

[29] M. Kaup, H.G. Schnering, Inorg. Chem. 33 (1994) 4718 - 4722.

[30] S. Georgakopoulou, R. Grondelle, D. van der Zwan, Biophys. J. 86 (2004) 3010 - 3022.

[31] S. Georgakopoulou, R. Grondelle, D. van der Zwan, J. Phys. Chem. B. 110 (2006) 3344 3353.

[32] E.H. Strickland D. Mercola, Biochemistry 15 (1976) 3875 - 3884.

[33] J. Goldman F.H. Carpenter, Biochemistry 13 (1974) 4566 - 4574.

[34] S. Superchi, E. Giorgio, C. Rosini, Chirality 16 (2004) $422-451$.

[35] J. Seibt, A. Lohr A, F. Würthner, V. Engel, Phys. Chem. Chem. Phys. 9 (2007) 6214 6218.

[36] A. Amirbahman, A.L. Reid, T.A. Haines, J.S. Kahl, C. Arnold, Environ Sci Technol 36 (2002) 690-695.

[37] S. Yoon, L.M. Diener, P.R. Bloom, E.A. Nater, W.F. Bleam, Geochim. et Cosmochim. Acta. 69 (2005) 1111-1121. 
[38] D.J. Rabenstein. R.S. Reid, Inorg. Chem. 23 (1984) 1246-1250.

[39] G.M. Vandal, W.F. Fitzgerald, K.R. Rolfnus, C.H. Lamborg, Water Air Soil Pollut. 80 (1995) $5929-528$.

[40] J. Ye, K. Sun, Y. Zhao, Y. Yu, C.K. Lee, J. Cao, J. Chem. Phys. 136 (2012) 245104 24518.

[41] A. Stirbet, Photosynth. Res. 116 (2013) 189 - 214.

[42] A. Freer, S. Prince, K. Sauer, M. Papiz, A. Hawthornthwaite-Lawless, G. McDermott, R. Cogdell. R. Isaacs, Structure 4 (1996) 449 - 462.

[43] K.H. Summer, J. Lichtmannegger, B. Michalke, N.L. Bandow, D.W. Choi, A.A. DiSpirito, B. Michalke, J. Trace Elem. Med. Biol. 25 (2011) 36 - 41.

[44] H. Zischka, J. Lichtmannegger, S. Schulz, S. Schmitt, N. Jägemann, D. Hamöller, L. Jennen, C. Rust, N. Larochette, L. Galluzzi, V. Chajes, N.L. Bandow, V.S. Gilles, A.A. DiSpirito, I. Esposito, M. Goettlicher, K.H. Summer, G. Kroemer, J. Clin. Invest. 121 (2011) $1508-1518$. 


\section{Figure Legends}

Fig. 1. Chemical structures of methanobactin from M. trichosporium OB3b (A) and Methylocystis strain SB2 (B). Abbreviation: M, metal that is coordinated by both rings and enethiol groups of methanobactin.

Fig 2. UV-visible absorption spectra of mb-SB2 as isolated and following the addition of: $\mathrm{HgCl}_{2}$ (A, B); $\mathrm{Hg}(\mathrm{CN})_{2}(\mathrm{C}, \mathrm{D})$ or $\mathrm{CH}_{3} \mathrm{ClHg}(\mathrm{E}, \mathrm{F})$. Absorbance changes at $247(\triangle), 255(\mathrm{O})$, $306(\mathbf{\Delta}), 338(\boldsymbol{\bullet}), 387(\boldsymbol{\square}), 399(\diamond)$ and 402/401 nm $(\diamond)$ following the addition of $\mathrm{HgCl}_{2}(\mathrm{~B}), \mathrm{Hg}(\mathrm{CN})_{2}(\mathrm{D})$, or $\mathrm{CH}_{3} \mathrm{HgCl}(\mathrm{F})$.

Fig. 3. Emission spectra from mb-SB2 following excitation at 341 (A, C and E) or $394 \mathrm{~nm}$ (B, D and $\mathrm{F}$ ) as isolated and following the addition of $\mathrm{HgCl}_{2}(\mathrm{~A}$ and $\mathrm{B}), \mathrm{Hg}(\mathrm{CN})_{2}(\mathrm{C}$ and $\mathrm{D})$, or $\mathrm{CH}_{3} \mathrm{HgCl}(\mathrm{E}$ and $\mathrm{F})$. Inserts emission intensities at $427(\mathrm{~A}), 434$ (C) or 440 following excitation at $341 \mathrm{~nm}$ and at 441 or $440(\square)$ and $610(\square)$ following excitation at $394 \mathrm{~nm}(\mathrm{~B}, \mathrm{D}$, and F).

Fig. 4. (A) UV-visible absorption $(--;-\longrightarrow$ Cirular dichroism $(-;-)$ spectra of mb-SB2 as isolated (_- - - ) and following acid hydrolysis of the oxazolone ring $(-\ldots-\longrightarrow$ UV-visible circular dichroism of mb-SB2 as isolated and following the addition of (B) 0.1, 0.2, 0.5 0.75, 1.0 and $2.0 \mathrm{CuCl}_{2}$; (C) $0.2,0.5,0.75,1.0$ and $2.0 \mathrm{HgCl}_{2}$; and (D) $0.2,0.5,0.75,1.0$ and $2.0 \mathrm{CH}_{3} \mathrm{HgCl}$ per mb-SB2. (E) Change in molar ellipticity at $215(\bullet), 264(\mathrm{O}), 300(\triangle), 322(\boldsymbol{\Delta}), 351(\square)$, and $430(\boldsymbol{\square}) \mathrm{nm}$ following the addition of $\mathrm{CuCl}_{2}$. Change in molar ellipticity at $242(\diamond), 300(\triangle), 347(\mathbf{\square})$, and $405(\square) \mathrm{nm}$ following the addition of $\mathrm{HgCl}_{2}$.

Fig. 5. A. Binding isotherm following the addition of $\mathrm{HgCl}_{2}$ to $\mathrm{mb}-\mathrm{SB} 2$. B. The binding isotherms for the second and third binding sites of $\mathrm{HgCl}_{2}$ of mb-SB2. C. The binding 
isotherm following the addition of $\mathrm{CH}_{3} \mathrm{HgCl}$ to $\mathrm{mb}-\mathrm{SB} 2(\odot)$ and following a $2000 \mathrm{cal}$ per mole adjustment to the binding isotherm $(\bullet)$. D. The binding isotherm following the addition of $\mathrm{Hg}(\mathrm{CN})_{2}$ to mb-SB2. The solid lines in panels B, C and D shows the curve fitting for a two-site binding algorithm.

Fig. 6. Ratio of $\mathrm{Hg}$ to $\mathrm{Cu}$ bound to mb-SB2 following incubaction of the mb-SB2 in solutions containing $\mathrm{Cu}^{2+}, \mathrm{Hg}^{2+}$ and mb-SB2 in molar ratios of 0.25:0.25:1, 0.5:0.5:1, 1:1:1, 1.5:1.5:1, and 2:2:1, respectively. Error bars represent the pooled standard deviations. 


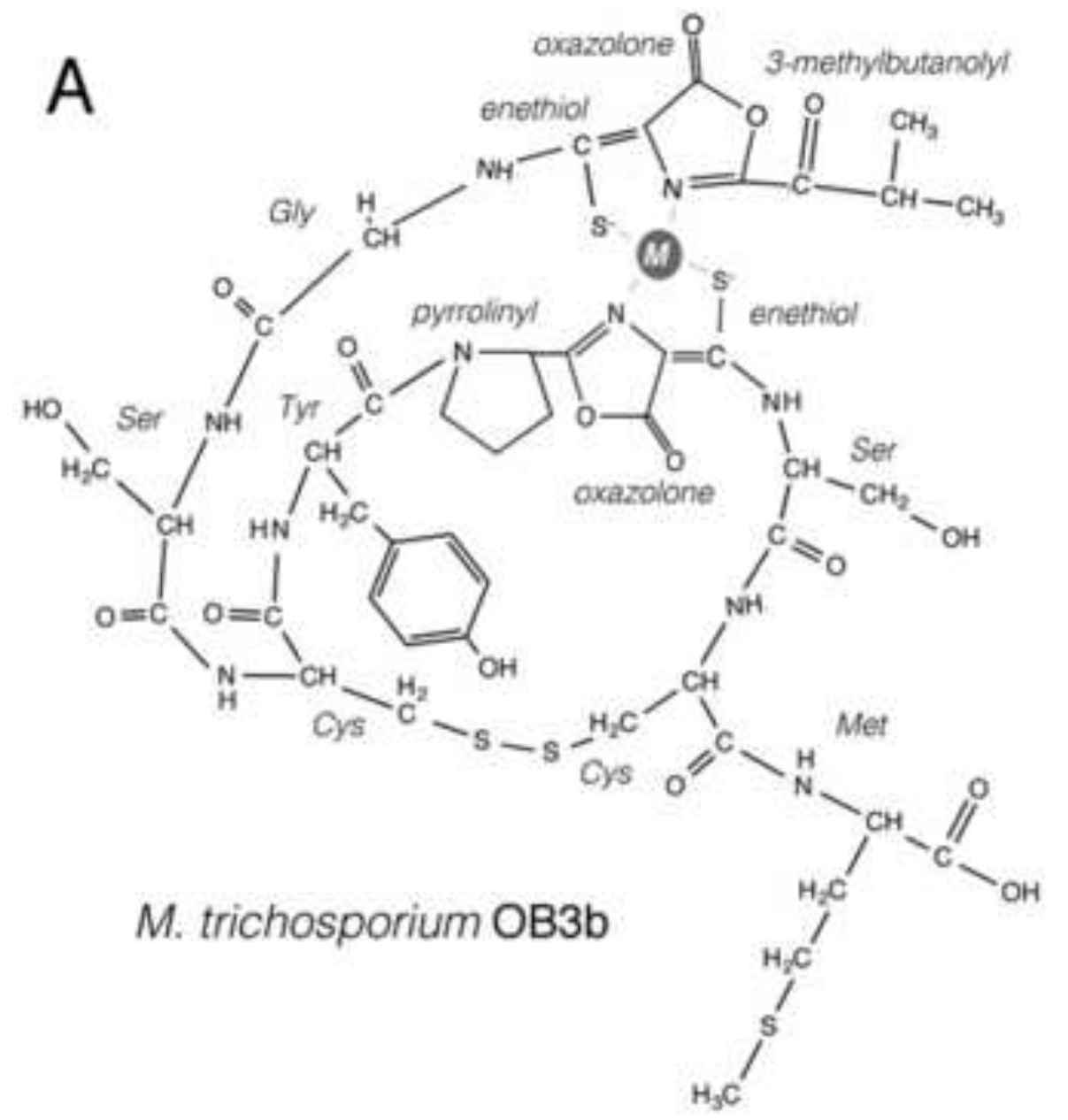

B

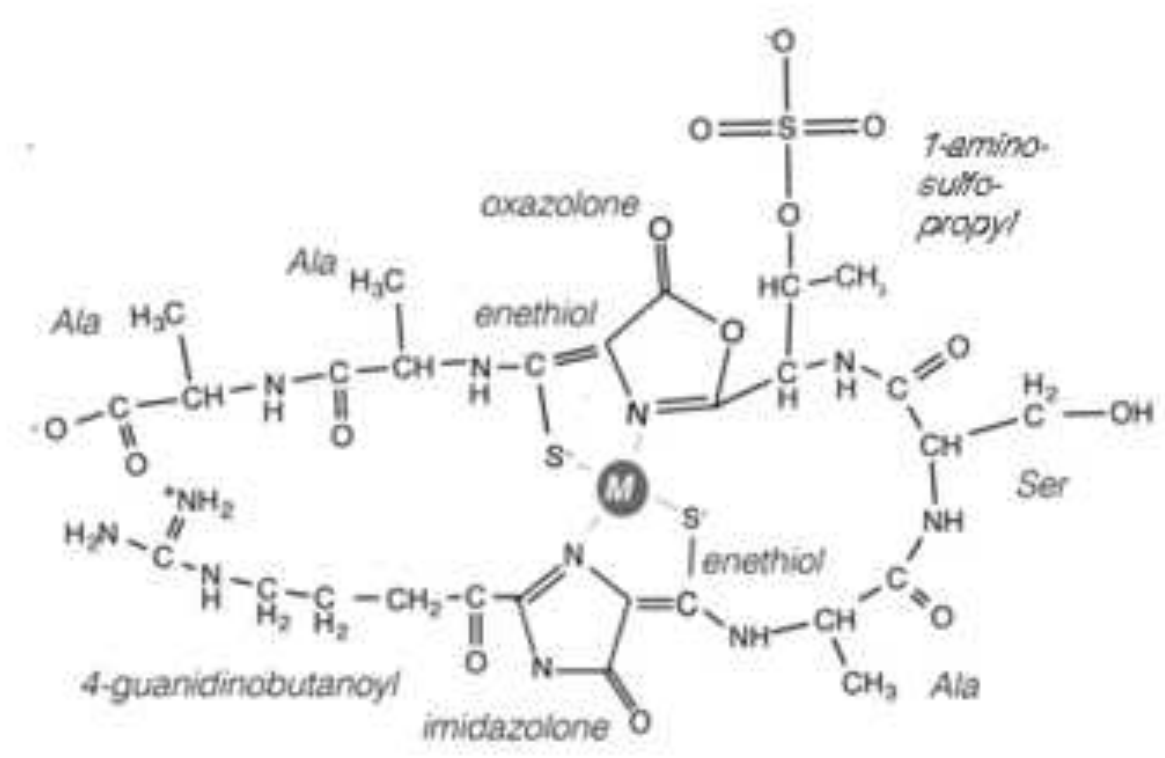

Methylocystis strain SB2

Fig. 1 

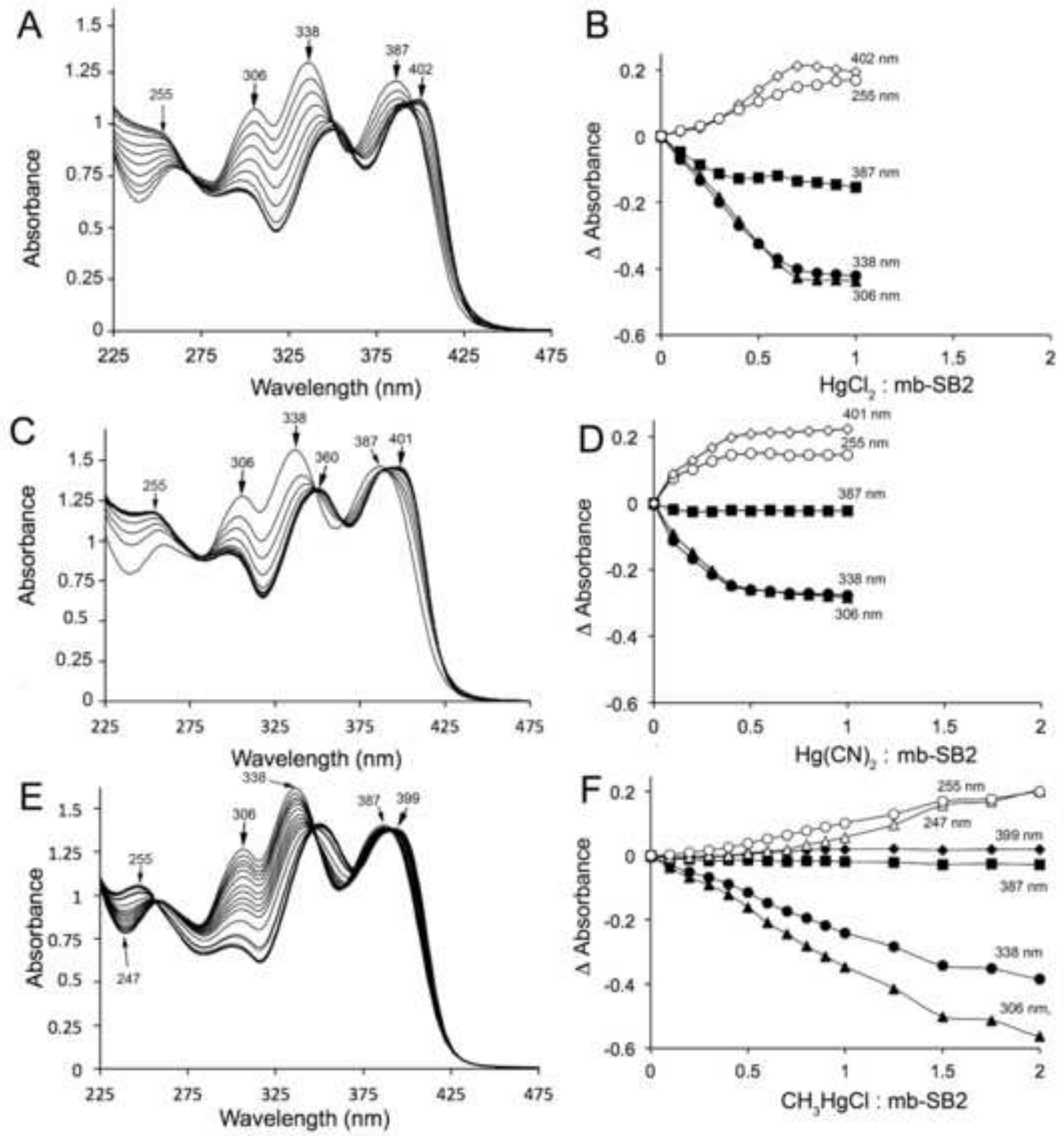

Fig 2 

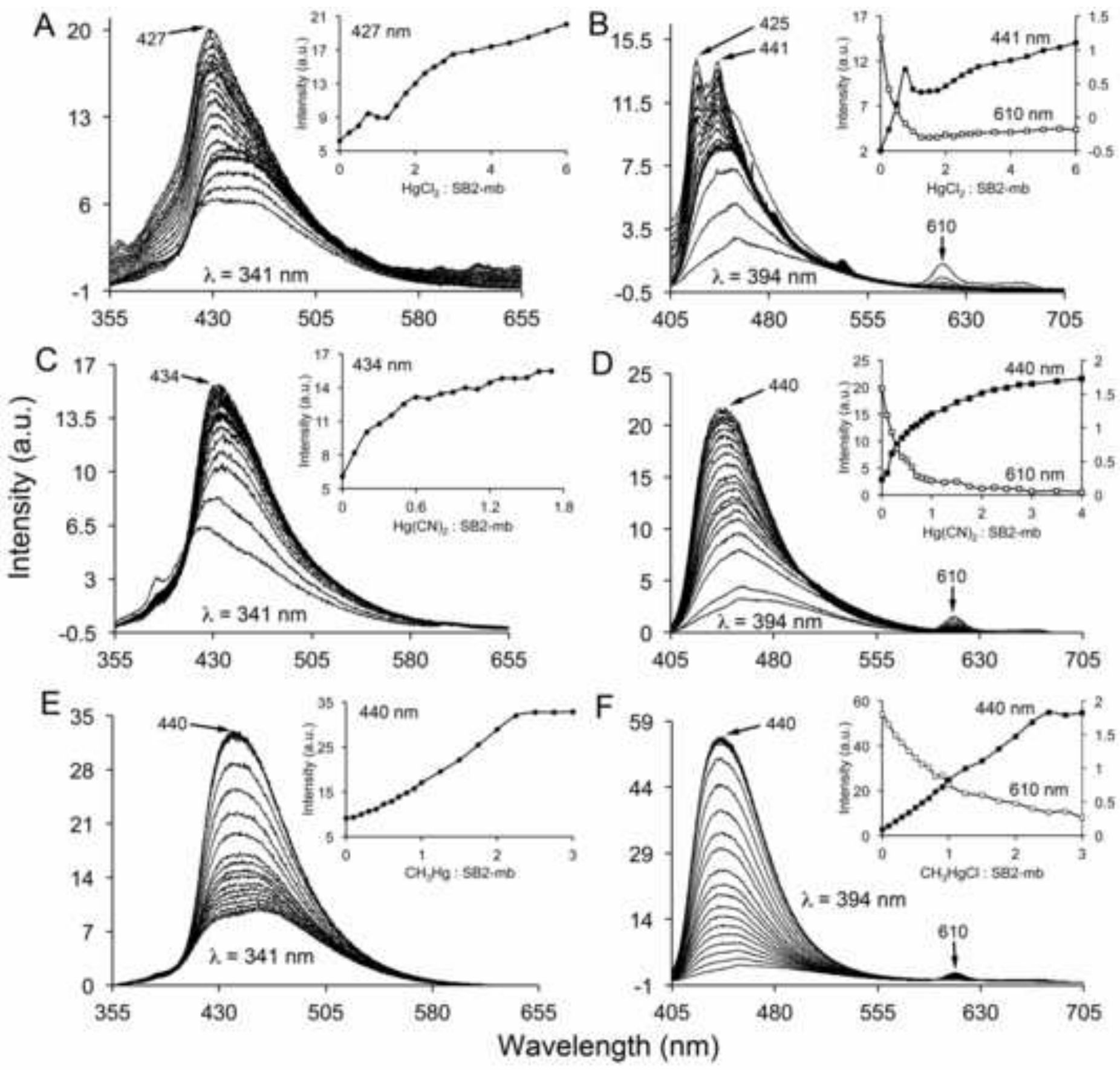

Fig. 3 

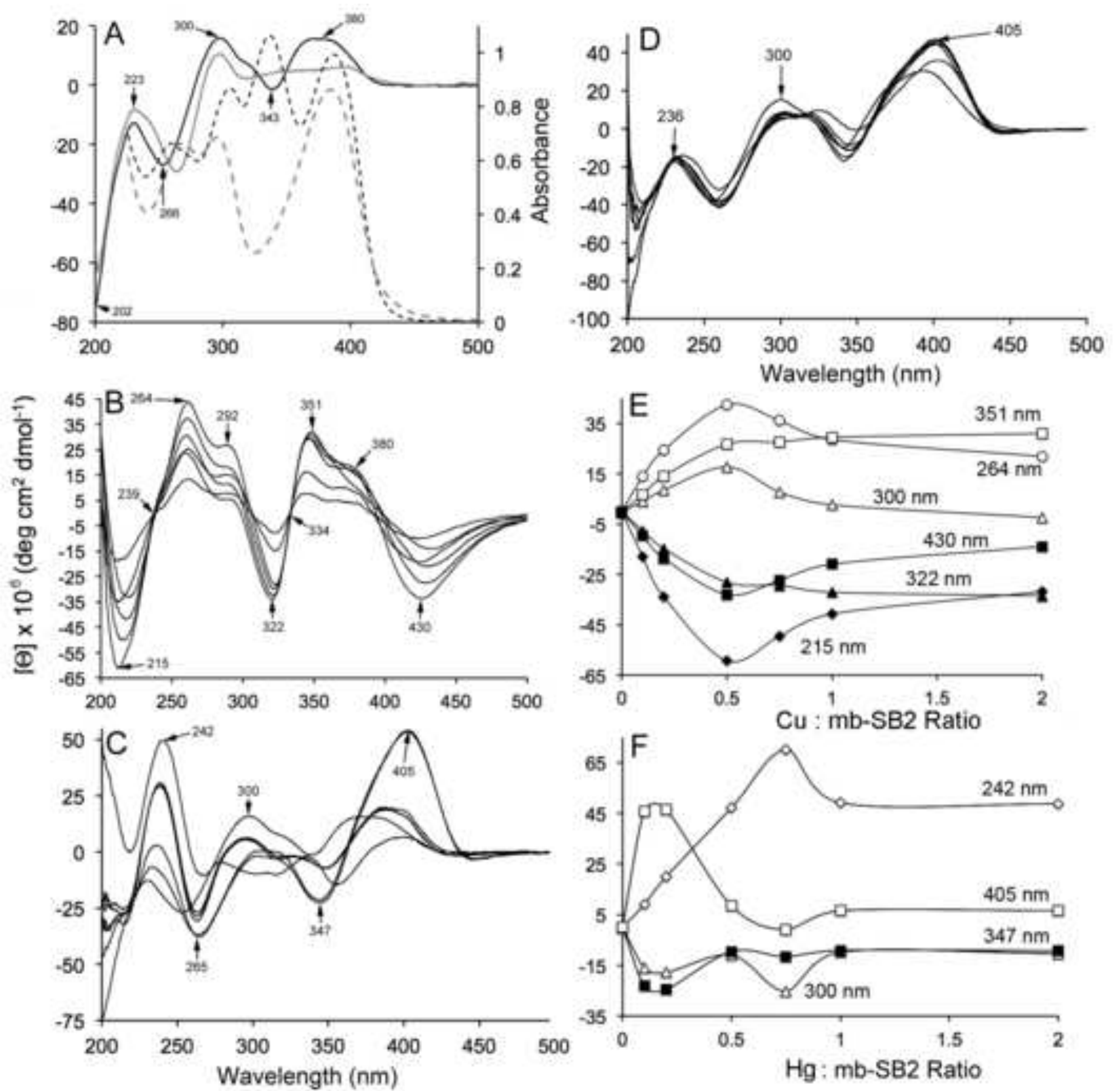

Fig. 4 

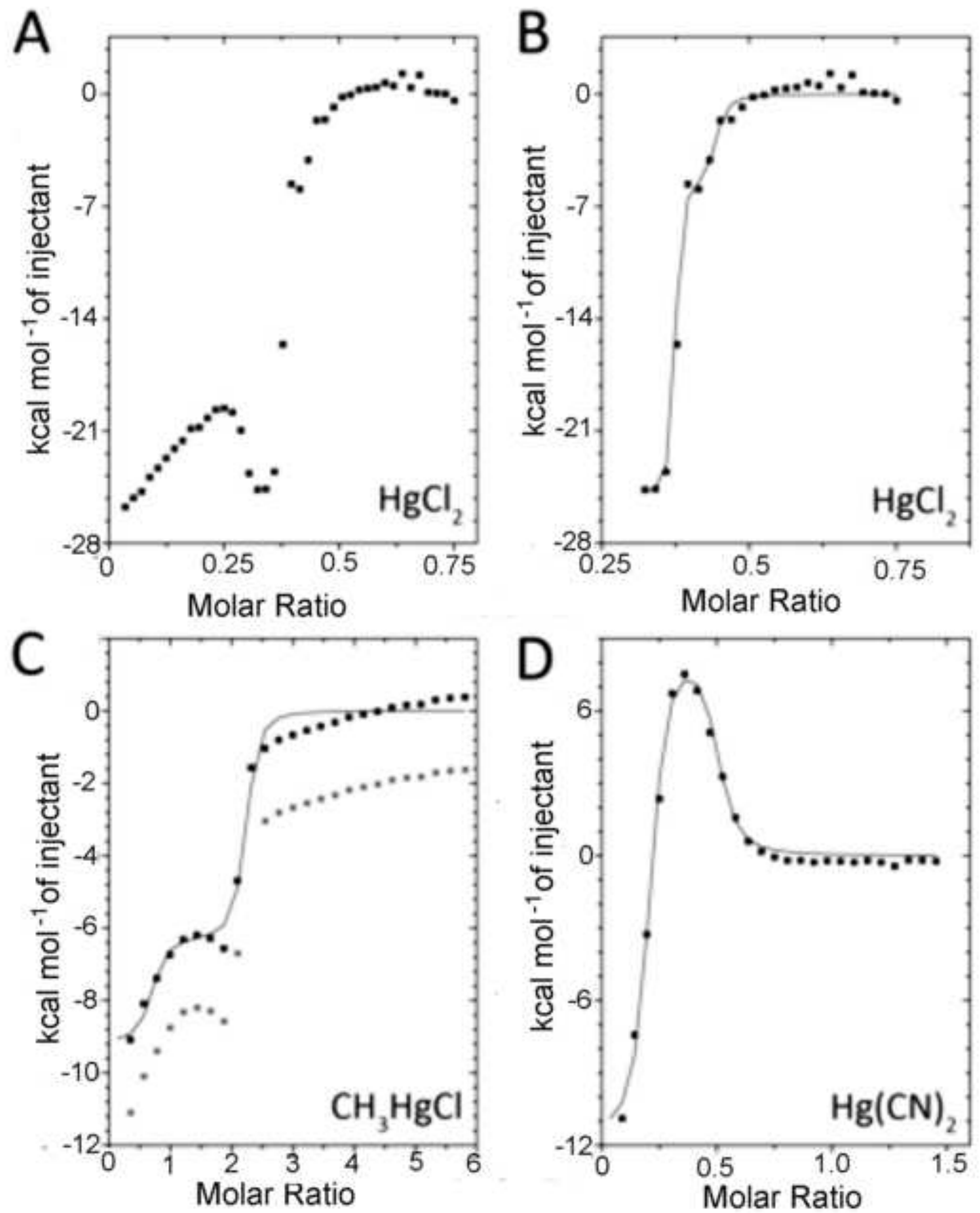

Fig. 5 


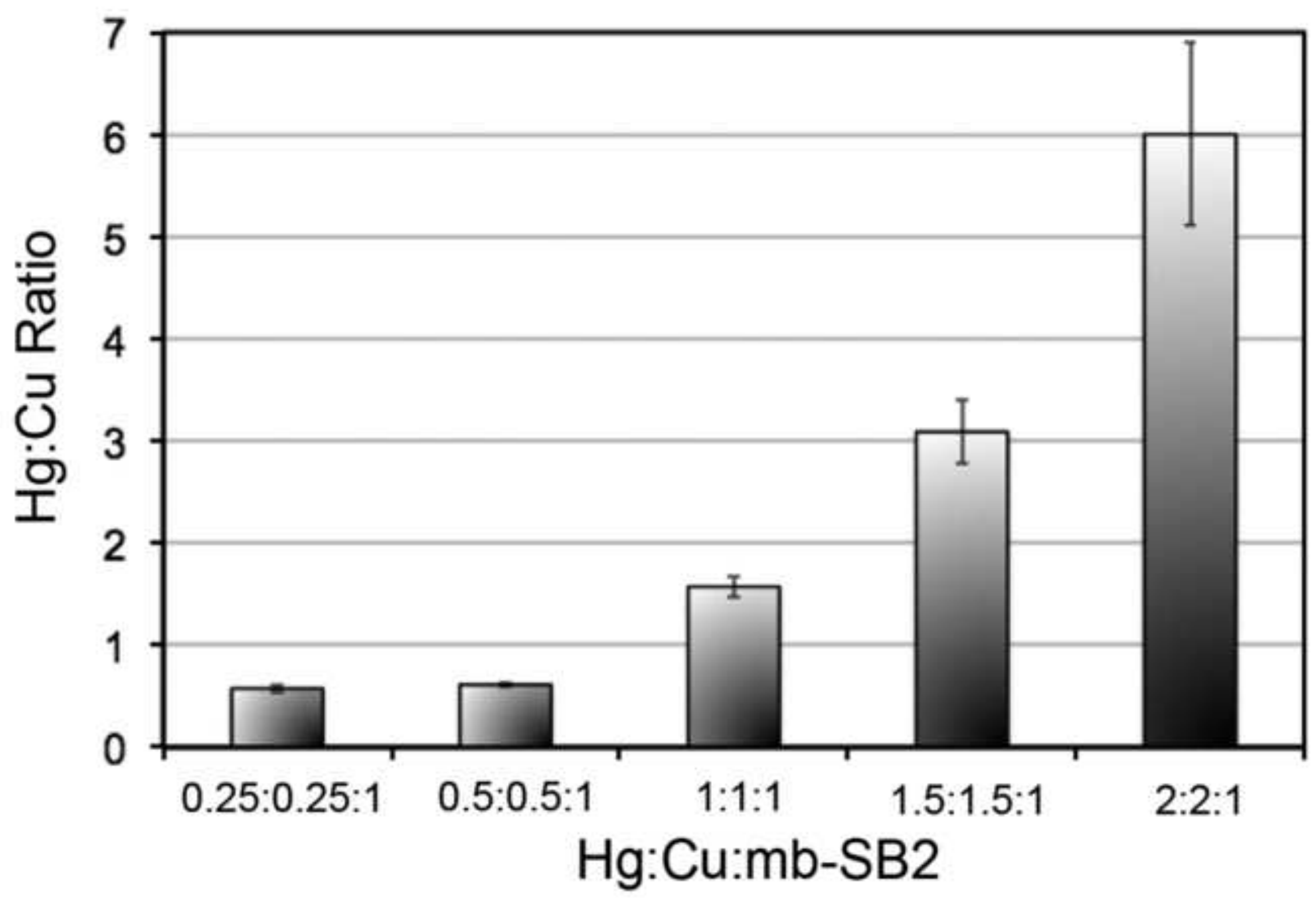

Fig. 6 
Table 1. Thermodynamic parameters for $\mathrm{HgCl}_{2}, \mathrm{Hg}(\mathrm{CN})_{2}$ and $\mathrm{CH}_{3} \mathrm{ClHg}$ binding to mb-SB2 at $25^{\circ} \mathrm{C}$.

\begin{tabular}{|c|c|c|c|}
\hline Parameter & $\mathrm{HgCl}_{2}$ & $\mathrm{CH}_{3} \mathrm{HgCl}$ & $\mathrm{Hg}(\mathrm{CN})_{2}$ \\
\hline 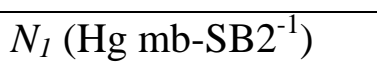 & $\mathrm{UTF}^{\dagger}$ & 0.62 & 0.19 \\
\hline$K_{l}\left(\mathrm{M}^{-1}\right)$ & UTF & $1.2 \times 10^{8}$ & $7.5 \times 10^{7}$ \\
\hline$\Delta \mathrm{H}_{1}\left(\mathrm{cal} \mathrm{mol}^{-1}\right)$ & UTF & $-11,190 *$ & -11800 \\
\hline$\Delta \mathrm{S}_{1}\left(\mathrm{cal} \mathrm{mol}^{-1} \mathrm{deg}^{-1}\right)$ & UTF & 6.07 & -3.55 \\
\hline$\Delta \mathrm{G}_{1}\left(\mathrm{cal} \mathrm{mol}^{-1}\right)$ & UTF & $-13,000^{*}$ & $-10,742$ \\
\hline 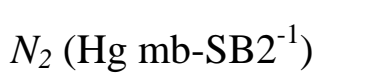 & 0.37 & 1.52 & 0.30 \\
\hline$K_{2}\left(\mathrm{M}^{-1}\right)$ & $7.5 \times 10^{9}$ & $1.7 \times 10^{6}$ & $1.8 \times 10^{6}$ \\
\hline$\Delta \mathrm{H}_{2}\left(\mathrm{cal} \mathrm{mol}^{-1}\right)$ & $-25,000$ & $-8,300 *$ & 9,000 \\
\hline$\Delta \mathrm{S}_{2}\left(\mathrm{cal} \mathrm{mol}^{-1} \mathrm{deg}^{-1}\right)$ & -38.7 & 7.4 & 58.8 \\
\hline$\Delta \mathrm{G}_{2}\left(\mathrm{cal} \mathrm{mol}^{-1}\right)$ & $-13,462$ & $-10,506^{*}$ & $-8,531$ \\
\hline 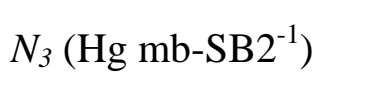 & 0.07 & - & - \\
\hline$K_{3}\left(\mathrm{M}^{-1}\right)$ & $6.87 \times 10^{6}$ & - & - \\
\hline$\Delta \mathrm{H}_{3}\left(\mathrm{cal} \mathrm{mol}^{-1}\right)$ & -5800 & - & - \\
\hline$\Delta \mathrm{S}_{3}\left(\mathrm{cal} \mathrm{mol}^{-1} \mathrm{deg}^{-1}\right)$ & 11.8 & - & - \\
\hline$\Delta \mathrm{G}_{3}\left(\mathrm{cal} \mathrm{mol}^{-1}\right)$ & -9318 & - & - \\
\hline$\chi^{2}$ & $8.36 \times 10^{5}$ & $1.48 \times 10^{5}$ & $2.04 \times 10^{5}$ \\
\hline
\end{tabular}

*calculated values following a $2000 \mathrm{cal} \mathrm{mol}^{-1}$ shift.

${ }^{\dagger}$ UTF, unable to fit 


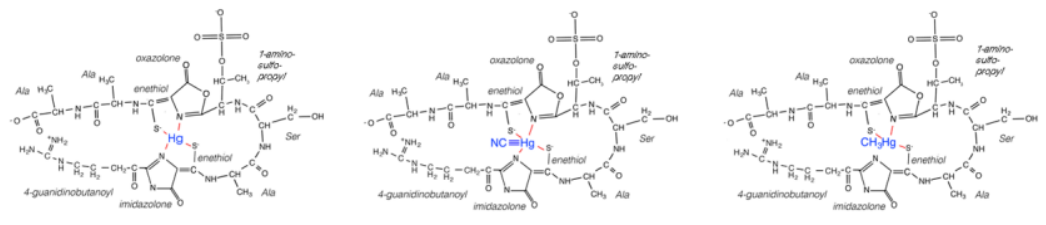


Synopsis

Chemical structures for methanobactin from Methylocystis strain SB2 and proposed corrodination of $\mathrm{Hg}^{2+}, \mathrm{Hg}(\mathrm{CN})_{2}$ and $\mathrm{CH}_{3} \mathrm{Hg}^{+}$. 